THURSDAY, DECEMBER 6, I877

\section{TECHNICAL EDUCATION}

DROF. HUXLEY has seized the occasion afforded him by his promise to aid the Working Man's Club and Institute Union by contributing to their present series of fortnightly lectures, to state his opinion on a question which, as we have already informed our readers, has lately been exercising the minds of some of the most influential members of various city companies.

For some time past a joint committee, representing the most important among these bodies, has been endeavouring to obtain information as to the best means of applying certain of their surplus funds to the assistance of what is called technical education, and there is little doubt that a proposal for a huge technical university, made some time ago, and the discussion which took place in connection with that proposal, has had somewhat to do in leading to the present condition of affairs.

Prof. Huxley and some four or five other gentlemen have been appealed to by this joint committee to send in reports on what they consider the best way to set about the work, and it is from this point of view that Prof. Huxley's lecture is so important. It was not merely fresh and brilliant and full of good things, as all his lectures are, but is doubtless an embodiment of his report to the joint committee.

We are rejoiced, therefore, to see that Prof. Huxley is at one with the views which we have all along expressed in NATURE, namely, that, after all, the mind is the most important instrument which the handicraftsman, whether he be a tinker or a physicist, will ever be called upon to use, and that therefore a technical education which teaches him to use a lathe, or a tool, or a loom, before he has learned how to use his mind, is no education at all.

Prof. Huxley not only defined technical education as the best training to qualify the pupil for learning technicalities for himself, but he stated what be considered such an education might be, and how the city funds can be best spent in helping it on.

Besides being able to read, write, and cipher, the student should have had such training as should have awakened his understanding and given him a real interest in his pursuit. The next requirement referred to was some acquaintance with the elements of physical science-a knowledge rudimentary, it might be, but good and sound, so far as it went, of the properties and character of natural objects. The professor is also of opinion that it is eminently desirable that he should be able, more or less, to draw. The faculty of drawing, in the highest artistic sense, was, it was conceded, like the gift of poetry, inborn and not acquired; but as everybody almost could write in some fashion or other, so, for the present purpose, as writing was but a kind of drawing, everybody could more or less be supposed to draw. A further desideratum was some ability to read one or two languages besides the student's own, that he might know what neighbouring nations, and those with which we were most mixed up, were doing, and have access to valuable sources of information which would otherwise be sealed to him. But above all-and this the speaker thought was the most essential condition-the pupil should have kept in all its bloom the freshness and youthfulness of his mind, all the vigour and elasticity proper to that age. Prof. Huxley then went on to explain that this freshness and vigour should not have been washed out of the student by the incessant labour and intellectual debauchery often involved in grinding for examinations.

We gather from this part of the address-we shall refer to the others by and by-that so far as Prof. Huxley's advice goes we are not likely to see any great expenditure of the money of the ancient city corporations either in the erection of a huge "practical" university or in the creation of still another "Examining Board." How then does he propose to spend it?

Here we come to a substantial proposal, which Prof. Huxley may consider to be the most important part of his address. What is wanted, he considers, is some machinery for utilising in the public interest special talent and genius brougbt to light in our schools. "If any Government could find a Watt, a Davy, or a Faraday in the market, the bargain would be dirt cheap at 100,000l." Referring to his saying when he was a member of the London School Board that he should like to see a ladder by which a child could climb from the gutter to the highest position in the State, he dwelt upon the importance of some system by which any boy of special aptitude should be encouraged to prolong his studies, to join art and science classes, and be apprenticed, with a premium if necessary. In the case of those who showed great fitness for intellectual pursuits they might be trained as pupilteachers, brought to London, and placed in some collegiate institution or training school. In this way the money of the guilds would be spent in aiding existing teaching systems, in which, on the whole, an enormous progress was acknowledged.

It is true the architects of London would not have the opportunity of immortalising themselves by erecting an imposing edifice, but, on the other hand, the infuence of the Guilds might be felt whenever there was a handicraft to foster, or a potential Watt to be sought out.

We do not imagine that it is Prof. Huxley's idea that there shall be no local representation of the city's new activity and influence; the reference to the training of teachers, we fancy, and other remarks here and there, seem to point to some such institution as the École Normale of Paris, where the best and most practical scientific teaching could be carried on. Every one knows how much room there is for such an institution as this, but on this little money need be spent, "so far as bricks and mortar are concerned, as little money is needed to equip such laboratories as are really meant for work.

There is an advantage in such lectures as these by no means limited to the expression of opinion on the part of the speaker. The slow and sure way in which science is taking a hold upon our national progress is well evidenced by the fact that the daily press can now no longer ignore such outcomes as these, and hence it is that they do good beyond the mere boundary of the question under discussion. They show the importance of, and foster interest in, the general question of intellectual and scientific progress.

The Times agrees in the main with the kind of educa

VOL, XVII, - No. 423 
tion to be given, and holds that "What is needed is to give a man the intelligence, the knowledge of general principles, combined with the habits of correct observation and quick perception, which will enable him afterwards to master the technicalities of his art, instead of becoming a slave to them. No objection can be taken to the advice that, for this purpose, a lad, after learning to read, write, and cipher, should acquire some facility in drawing, and should be familiarised with the elements of physical science. The importance of the latter study for this particular purpose is, indeed, unquestionable, and even paramount, for a handicraftsman is dealing exclisively with physical objects in his work, and his skill in applying the processes of his craft will vary in great measure with his knowledge of the scientific principles on which they depend."

But we fancy that the Times writer does not look upon this scientific part of education quite as the lecturer does, for he proceeds to add: "There can be little doubt, for instance, that many of the perils of mining might be averted if the miners were alive to the scientific reasons of the precautions they are urged to adopt. Many an improvement, probably, which now escapes the eye of a man who adheres slavishly to the rules of his craft would occur to him if he were applying them with conscious intelligence."

The Times, however, considers that the school-time is too short for the languages, and curiously enough drives its point home by saying a harder thing about the Greek and Latin of our public schools than Prof. Huxley has ever done; while, on the other hand, the Daily News points out that Prof. Huxley this time may have raised a hornet's nest about his ears by the unduly reasonable tone of his demands.

The Daily News then adds:-- "A man of science who does not demand that from the earliest age an hour a day shall be devoted to each of the ologies may be regarded as a traitor to his cause." For our part we know of no man of science who has ever made such a demand; and a careful examination of what men of science have said on this point for the last ten years will show that these extreme views to which reference is here made are not those of men of science at all.

It will be well also if the strong language used in connection with the multiple examinations of the present day brings that question well before the bar of public opinion. The Times is " sorry to see another flout thus inflicted, in passing, on that system of examinations which, like most good institutions, may do harm to the few, but is indispensable as a motive for work to the great majority." Prof. Huxley has expressed the views of most of the leading teachers in this country with regard to the effect of these examinations upon the students, and he might have referred to their reflex action on the examiner. Go into a company of scientific men, and observe the most dogmatic, the most unfruitful, and the least modest among them, you will find that this man is, as we may say, an examiner by profession. Speak to him of research or other kindred topics, he will smile at you-his time is far too precious to be wasted in discussing such trivialities; like his examinees, he finds they do not pay. The example set by Germany in this respect, both as regards students and professors, cannot be too often referred to, and there is little doubt that the love of science for its own sake which has made Germany what she now is intellectually, has sprung to a large extent from the fact that each young student sees those around him spurred from within and not from without. Noblesse oblige.

In point of fact so far as our future scientific progress is concerned the examination question is as important as that connected with the kind of education to be subsidised by the city guilds, and it is important, seeing that our legislators will, in the coming time, have to give their opinion on these subjects as well as on beer, vivisection, and contagious diseases, that in Prof. Huxley's language "by the process called distillatio per ascensum-distillation upwards--there should in time be no member of Parliament who does not know as much of science as a scholar in one of our e!ementary schools."

\section{NORTH AMERICAN STARFISHES}

Menoirs of the Museum of Comparative Zoology at Harvard College. Vol. v. No. I. North American Starfishes. By Alexander Agassiz. With Twenty Plates. (Cambridge, U.S., I877.)

THIS memoir consists of two parts. The first con1 tains a history of the Embryology of the Starfish, which is substantially the same as that published in 1364 as Part I., Vol. v., of Prof. Agassiz's "Natural History of the United States." The author has, however, added notes on the points where additions have been made by subsequent investigations. The second part treats of the solid parts of some North American starfishes.

The plates accompanying the second part were intended to form part of one of Prof. L. Agassiz's volumes of "Contributions to the Natural History of the United States," and have been drawn for more than twelve years. The late Prof. Agassiz intended to add them as illustrating the anatomy of several of the more common American species.

Under these circumstances the memoir is wanting in the completeness that distinguishes some of the other Memoirs of this series, such as that "On the Ophiuridæ," by Lyman, and that "On the Echini," by Alexander Agassiz; but though the subject of the Starfishes as thus presented is incomplete, it is beyond a doubt that we have here a work of great value that will serve not only as illustrating a number of American species, and showing the systematic value of characters often almost completely overlooked, but as determining the homology of several genera not previously figured, and of which the details of the solid parts are fully given.

The arrangement of the star-fishes into families adopted does not materially differ from that given by Perrier in his revision of the group. No general list, much less a synonymic catalogue, as in the case of Echini, is given; and this because the number of species in the hands of Prof. Perrier, from the Florida dredgings, as well as those found by the Challenger expedition, have added a number of remarkable forms not yet wholly determined to the American starfish fauna.

The author reminds us that the transformations peculiar to the Echinodernis constitute neither a metamorphosis nor a case of alternate generation. The egg becomes the embryo larva. Nothing essential is lost during the 